\title{
Synthesis and Antimicrobial Activity of 7-Hydroxy-3',4'-Methylenedioxy- and 7-Benzyloxy-3',4'-Methylenedioxy Flavanones
}

\author{
R. Ali*, A. Rahim, A. Islam \\ Department of chemistry, University of Rajshahi, Rajshahi-6205, Bangladesh \\ Received 22 January 2017, accepted in final revised form 11 June 2017
}

\begin{abstract}
7-Hydroxy-3',4'-methylenedioxy- and 7-benzyloxy-3',4'-methylenedioxy flavanones have been synthesized starting from 2,4-dihydroxyacetophenone. Subsequently biocidal activities of the flavanones have been investigated along with their corresponding chalcones against some bacterial and fungal strains. 2'-Hydroxy-4'-benzyloxy-3,4-methylenedioxy chalcone (5) and its corresponding flavanone (7) showed good antibacterial and antifungal activities against some selected bacterial and fungal strains. On the other hand, 2', $4^{\prime}-$ dihydroxy-3,4-methylenedioxy chalcone (4) showed no antibacterial and antifungal activities while its corresponding flavanone (6) showed a little antibacterial activity only at higher concentration but did not show antifungal activity. The synthesized chalcones and flavanones have been characterized using UV-Vis, IR and ${ }^{1} \mathrm{H}$ NMR spectral data together with elemental analysis.
\end{abstract}

Keywords: Aldol reaction; Chalcone; Flavanone; Antibacterial activity; Antifungal activity.

(C) 2017 JSR Publications. ISSN: 2070-0237 (Print); 2070-0245 (Online). All rights reserved. doi: http://dx.doi.org/10.3329/jsr.v9i3.31229

J. Sci. Res. 9 (3), 297-306 (2017)

\section{Introduction}

Flavonoid is classified into flavones, flavanones, chalcones, flavanols, isoflavones, flavonols and flavanonols [1] and are occurring widely within the plant kingdom [2-7]. Flavonoids are found in fruits, vegetables, nuts, seeds and flowers as well as in teas and wines and are important constituent of human diet [1,8,9]. Flavanone (dihydroflavone) is one of the minor subclasses of flavonoids and is found extensively in citrus fruits oranges, mandarins, tangors, tangelos, grapefruit, lemons, lines and tomatoes [1,7]. Synthesis of flavonoid compounds have attracted considerable attention because of their significant biocidal [9-11] and pharmaceutical [12-16] effects. Because of this exciting biological activities, many flavonoid compounds have been synthesized and studied their antibacterial and antifungal activities [17-23].

\footnotetext{
* Corresponding author: roushown@ru.ac.bd
} 
In this manuscript, we describe syntheses of $2^{\prime}, 4^{\prime}$-dihydroxy-3,4-methylenedioxy chalcone 4 and 2'-hydroxy-4'-benzyloxy-3,4-methylenedioxy chalcone $\mathbf{5}$, and their conversion into corresponding flavanones (6 and 7), respectively using $\mathrm{H}_{2} \mathrm{SO}_{4} / \mathrm{EtOH}$. Both the chalcones and flavanones were screened for their antibacterial and antifungal activities against four human pathogenic bacteria, viz., Shigella dysenteriae $\left(\mathrm{G}^{-}\right)$, Pseudomonas aeruginosa $\left(\mathrm{G}^{-}\right)$, Sarcina lutea $\left(\mathrm{G}^{+}\right)$, Bacilus subtillis $\left(\mathrm{G}^{+}\right)$, and five plants as well as molds fungi, viz. Penicillium sp., Aspergillus nigar, Aspergillus flavus, Candida albicans, Colletorichum gloeosporioides.

\section{Materials and Method}

Melting points were recorded on Gallenkamp apparatus and were uncorrected. The IR spectra $(\mathrm{KBr})$ were measured using a Shimadzu, DR-8001 spectrophotometer. The ${ }^{1} \mathrm{H}$ NMR spectra $\left(\mathrm{CDCl}_{3}\right)$ were recorded on a Brucker WH $400 \mathrm{MHz}$ instrument with TMS as an internal standard. The UV-Vis spectra were recorded on a LKB 4053 spectrophotometer using $\mathrm{MeOH}$ as a solvent. The purity of the compounds was checked by TLC.

\subsection{Synthesis of 2-hydroxy-4-benzyloxy acetophenone $\left(2, \mathrm{C}_{15} \mathrm{H}_{14} \mathrm{O}_{3}\right)$}

A mixture of 2,4-dihydroxyacetophenone (1,50 mmol, $7.61 \mathrm{~g})$, benzyl chloride (1.1 eqv., $55 \mathrm{mmol}, 6.93 \mathrm{~g})$, anhydrous potassium carbonate $(18 \mathrm{~g})$ and small amount of potassium iodide in acetone $(250 \mathrm{~mL})$ was refluxed for $8 \mathrm{~h}$. Potassium salts were filtered off and the filtrate was evaporated to dryness. The reaction mixture was subjected to column chromatography over silica gel and eluted successfully with petroleum spirit-benzene (1:4) and obtained 2-hydroxy-4-benzyloxy acetophenone $\mathbf{2}$ as single product. It was crystallized from ether as pale yellow needles, yield $50 \%, \mathrm{mp} .110-111^{\circ} \mathrm{C}, \mathrm{R}_{\mathrm{f}} 0.79$ (benzene:acetone; 9:1). It gave a deep brown color with alcoholic ferric chloride solution, which indicated the presence of free phenolic group.

Anal. Found: C, 74.71\%; H, 5.46\%; Cal. for $\mathrm{C}_{15} \mathrm{H}_{14} \mathrm{O}_{3} ; \mathrm{C}, 74.38 \%$; $\mathrm{H}, 5.73 \%$.

$\mathrm{UV} \lambda_{\max }^{\mathrm{MeOH}}: 237$ and $288 \mathrm{~nm}$. IR (KBr): 3462, 3026, 2928, 1645, 1560, 1507, 1090, 1021 $\mathrm{cm}^{-1} .{ }^{1} \mathrm{H}$ NMR $\left(\mathrm{CDCl}_{3}\right): \delta 2.50\left(\mathrm{~s}, 3 \mathrm{H},-\mathrm{COCH}_{3}\right), 5.02\left(\mathrm{~s}, 2 \mathrm{H},-\mathrm{O}-\mathrm{CH}_{2}-\mathrm{C}_{6} \mathrm{H}_{5}\right), 6.46(\mathrm{~d}, 1 \mathrm{H}$, $J=7.8 \mathrm{~Hz}, \mathrm{H}-5), 6.49$ (s, $1 \mathrm{H}, \mathrm{H}-3), 7.26-7.28\left(\mathrm{~m}, 5 \mathrm{H},-\mathrm{O}-\mathrm{CH}_{2}-\mathrm{C}_{6} \mathrm{H}_{5}\right), 7.58(\mathrm{~d}, 1 \mathrm{H}, J=7.8$ $\mathrm{Hz}, \mathrm{H}-6), 11.68$ (s, 1H, OH).

\subsection{Synthesis of 2', 4'-dihydroxy-3, 4-methylenedioxychalcone $\left(4, \mathrm{C}_{16} \mathrm{H}_{12} \mathrm{O}_{5}\right)$}

A mixture of 2,4-dihydroxyacetophenone (1, $14 \mathrm{mmol}, 2 \mathrm{~g})$ and 3, 4-methylenedioxy benzaldehyde $(3,1.2 \mathrm{~g})$ in $5 \%$ ethanolic solution of $\mathrm{KOH}(15 \mathrm{~mL})$ was kept at room temperature for about $75 \mathrm{~h}$. The reaction mixture was diluted with ice cold water, acidified with cold dil. $\mathrm{HCl}$ and extracted with ether. The ether layer was washed with water, dried over anhydrous $\mathrm{Na}_{2} \mathrm{SO}_{4}$ and evaporated to dryness. The reaction mixture was subjected to column chromatography over silica gel. The elution was done with benzene-acetone 
(10:1) and crystallized from ether as pale yellow crystals, yield $78 \%$, m.p. $97-98^{\circ} \mathrm{C}, \mathrm{R}_{\mathrm{f}}$ 0.76 (benzene: acetone; 10:1). It gave a deep brown color with alcoholic ferric chloride solution, which indicated the presence of free phenolic group.

Anal. Found: C, 67.49\%; H, 4.36\%; Calc. for $\mathrm{C}_{16} \mathrm{H}_{12} \mathrm{O}_{5} ; \mathrm{C}, 67.61 \% ; \mathrm{H}, 4.26 \%$; UV $\lambda_{\max }^{\mathrm{MeOH}}: 230,265$ and $355 \mathrm{~nm}$. IR(KBr): 3410, 2907, 1675, 1617, 1569, 1504, 1490, 1459, 1439, 1407, 1372, 1354, 1336, 1310, 1284, 1271, 1242, 1161, 1130, 1098, 1038, $1026,975,935,916,867,816,759,748,721,666,623 \mathrm{~cm}^{-1} .{ }^{1} \mathrm{H} \mathrm{NMR}\left(\mathrm{CDCl}_{3}\right): \quad \delta 6.01$ (s, 2H, -O- $\left.\mathrm{CH}_{2}-\mathrm{O}-\right), 6.32\left(\mathrm{~s}, 1 \mathrm{H}, \mathrm{C}_{3}{ }^{\prime}-\mathrm{H}\right), 6.36\left(\mathrm{~d}, 1 \mathrm{H}, J=9 \mathrm{~Hz}, \mathrm{C}_{5}{ }^{\prime}-\mathrm{H}\right), 6.65$ (d, 1H, J = 8.6 $\left.\mathrm{Hz}, \mathrm{C}_{5}-\mathrm{H}\right), 6.82\left(\mathrm{~d}, 1 \mathrm{H}, J=8.6 \mathrm{~Hz}, \mathrm{C}_{6}-\mathrm{H}\right), 6.83\left(\mathrm{~s}, 1 \mathrm{H}, \mathrm{C}_{2}-\mathrm{H}\right), 7.20\left(\mathrm{~d}, 1 \mathrm{H}, J=16 \mathrm{~Hz}, \mathrm{C}_{\alpha^{-}}\right.$ $\mathrm{H}), 7.58,\left(\mathrm{~d}, 1 \mathrm{H}, J=9 \mathrm{~Hz}, \mathrm{C}_{6}{ }^{\prime}-\mathrm{H}\right), 7.61\left(\mathrm{~d}, 1 \mathrm{H}, J=16 \mathrm{~Hz}, \mathrm{C}_{\beta}-\mathrm{H}\right), 11.43\left(\mathrm{~s}, 1 \mathrm{H}, \mathrm{C}_{4}{ }^{\prime}-\mathrm{OH}\right)$, $11.58\left(\mathrm{~s}, 1 \mathrm{H}, \mathrm{C}_{2}{ }^{\prime}-\mathrm{OH}\right)$.

\subsection{Synthesis of 7-hydroxy-3', 4'-methylenedioxyflavanone $\left(6, \mathrm{C}_{16} \mathrm{H}_{12} \mathrm{O}_{5}\right)$}

The chalcone $4(0.5 \mathrm{~g})$ was cyclized by refluxing with $5 \%$ ethanolic sulphuric acid (25 $\mathrm{mL}$ ) for $30 \mathrm{~h}$. The reaction mixture was kept at room temperature for $24 \mathrm{~h}$. It was diluted with water and extracted by ether. The ether layer was washed with water, dried over anhydrous $\mathrm{Na}_{2} \mathrm{SO}_{4}$ and concentrated by evaporation. TLC examination of the residue showed several spots and the major product was purified by preparative TLC using nhexane-acetone (5:1) as developing solvent. The flavanone was obtained (190 mg) as white flakes with m.p. $178^{\circ} \mathrm{C}$. It showed white florescence spot in UV light, $R_{\mathrm{f}} 0.49$ (nhexane-acetone; 4:1). It gave greenish brown color with ferric chloride solution.

Anal. Found: C, 67.44\%; H, 4.39\%; Calc. for $\mathrm{C}_{16} \mathrm{H}_{12} \mathrm{O}_{5} ; \mathrm{C}, 67.61 \% \mathrm{H}, 4.26 \%$. UV $\lambda_{\max }^{\mathrm{MeOH}}: 232,281$ and $370 \mathrm{~nm}$. IR (KBr): 3405, 2922, 1647, 1597, 1569, 1544, 1473, 1446, 1430, 1381, 1346, 1326, 1296, 1266, 1245, 1126, 1151, 1110, 1025, 941, 918, 879, $862,849,833,811,778,760,747,681 \mathrm{~cm}^{-1} .{ }^{1} \mathrm{H} \mathrm{NMR}\left(\mathrm{CDCl}_{3}\right): \delta 3.08\left(\mathrm{dd}, 2 \mathrm{H}, \mathrm{C}_{3}-\mathrm{H}\right)$, $5.44\left(\mathrm{dd}, 1 \mathrm{H}, \mathrm{C}_{2}-\mathrm{H}\right), 6.01$ (s, 2H, $\left.-\mathrm{O}-\mathrm{CH}_{2}-\mathrm{O}-\right), 6.32$ (d, $\left.1 \mathrm{H}, J=8.6 \mathrm{~Hz}, \mathrm{C}_{6}-\mathrm{H}\right), 6.45(\mathrm{~s}, 1 \mathrm{H}$, $\left.\mathrm{C}_{8}-\mathrm{H}\right), 6.55\left(\mathrm{~m}, 1 \mathrm{H}, \mathrm{C}_{5}{ }^{\prime}-\mathrm{H}\right.$ and $\left.\mathrm{C}_{2}{ }^{\prime}-\mathrm{H}\right), 6.60,\left(\mathrm{~d}, 1 \mathrm{H}, J=9 \mathrm{~Hz}, \mathrm{C}_{6}{ }^{\prime}-\mathrm{H}\right), 7.51(\mathrm{~d}, 1 \mathrm{H}, J=8.6$ $\left.\mathrm{Hz}, \mathrm{C}_{5}-\mathrm{H}\right), 11.58$ (s, $\left.1 \mathrm{H}, \mathrm{C}_{7}-\mathrm{OH}\right)$.

\subsection{Synthesis of 2'-hydroxy-4'benzyloxy-3, 4-methylenedioxychalcone $\left(5, \mathrm{C}_{23} \mathrm{H}_{18} \mathrm{O}_{5}\right)$}

A mixture of 2-hyroxy-4-benzyloxy acetophenone (2,2 g) and 3,4-methylenedioxy benzaldehyde $(3,1.2 \mathrm{~g})$ in $5 \%$ ethanolic solution of $\mathrm{KOH}(15 \mathrm{~mL})$ was kept at room temperature for about $70 \mathrm{~h}$. The reaction mixture was diluted with ice cold water, acidified with cold dil. $\mathrm{HCl}$ and extracted with ether. The ether layer was washed with water, dried over anhydrous $\mathrm{Na}_{2} \mathrm{SO}_{4}$ and evaporated to dryness. The reaction mixture was subjected to column chromatography over silica gel. The elution was done with benzene-acetone (10:1) and crystallized from ether as pale yellow crystals, yield 70\%, m.p. 91-92 ${ }^{\circ} \mathrm{C}, \mathrm{R}_{\mathrm{f}}$ 0.75 (benzene: acetone: 10:1). It gave a deep brown color with alcoholic ferric chloride solution, which indicated the presence of free phenolic group.

Anal. Found: C, 73.74\%; H, 4.77\%; Calc. for $\mathrm{C}_{23} \mathrm{H}_{18} \mathrm{O}_{5} ; \mathrm{C}, 73.80 \% ; \mathrm{H}, 4.81 \%$. UV $\lambda_{\max }^{\mathrm{MeOH}}: 232,265$ and $360 \mathrm{~nm}$. IR (KBr): 3405, 2907, 1680, 1617, 1569, 1504, 1490, 
1459, 1439, 1407, 1372, 1354, 1336, 1310, 1284, 1271, 1242, 1161, 1130, 1098, 1038, $1026,975,935,916,867,816,759,748,721,666,623 \mathrm{~cm}^{-1} .{ }^{1} \mathrm{H} \mathrm{NMR}\left(\mathrm{CDCl}_{3}\right): \delta 5.09(\mathrm{~s}$, $\left.2 \mathrm{H},-\mathrm{O}-\mathrm{CH}_{2}-\mathrm{C}_{6} \mathrm{H}_{5}\right), 6.02$ (s, 2H, -O- $\left.\mathrm{CH}_{2}-\mathrm{O}-\right), 6.42\left(\mathrm{~d}, 1 \mathrm{H}, J=8.6 \mathrm{~Hz}, \mathrm{C}_{5}{ }^{\prime}-\mathrm{H}\right), 6.50$ (d, $\left.1 \mathrm{H}, J=8.6 \mathrm{~Hz}, \mathrm{C}_{5}-\mathrm{H}\right), 6.55\left(\mathrm{~d}, 1 \mathrm{H}, J=9 \mathrm{~Hz}, \mathrm{C}_{3}{ }^{\prime}-\mathrm{H}\right), 6.62\left(\mathrm{~s}, 1 \mathrm{H}, \mathrm{C}_{2}-\mathrm{H}\right), 6.65(\mathrm{~d}, 1 \mathrm{H}, J=$ $\left.8.6 \mathrm{~Hz}, \mathrm{C}_{6}-\mathrm{H}\right), 6.82\left(\mathrm{~d}, 1 \mathrm{H}, J=16 \mathrm{~Hz}, \mathrm{C}_{\alpha}-\mathrm{H}\right), 7.21-7.26\left(\mathrm{~m}, 5 \mathrm{H},-\mathrm{O}-\mathrm{CH}_{2}-\mathrm{C}_{6} \mathrm{H}_{5}\right), 7.55$ (d, $\left.1 \mathrm{H}, J=9 \mathrm{~Hz}, \mathrm{C}_{6}{ }^{\prime}-\mathrm{H}\right), 7.61\left(\mathrm{~d}, 1 \mathrm{H}, J=16 \mathrm{~Hz}, \mathrm{C}_{\beta}-\mathrm{H}\right), 11.58\left(\mathrm{~s}, 1 \mathrm{H}, \mathrm{C}_{2}{ }^{\prime}-\mathrm{OH}\right)$.

\subsection{Synthesis of 7-benzyloxy-3','-methylenedioxyflavanone $\left(7, \mathrm{C}_{23} \mathrm{H}_{18} \mathrm{O}_{5}\right)$}

The chalcone $5(0.5 \mathrm{~g})$ was cyclized by refluxing with $5 \%$ ethanolic sulphuric acid (25 $\mathrm{mL}$ ) for $35 \mathrm{~h}$. The reaction mixture was kept at room temperature for $24 \mathrm{~h}$. It was diluted with water and extracted with ether. The ether layer was washed with water, dried over anhydrous $\mathrm{Na}_{2} \mathrm{SO}_{4}$ and concentrated by evaporation. TLC examination of the residue showed several spots and the major product was purified by preparative TLC using nhexane-acetone (5:1) as developing solvent. The flavanone was obtained (180 $\mathrm{mg})$ as white flakes with m.p. $188{ }^{\circ} \mathrm{C}$. It showed white florescence spot in UV light, $\mathrm{R}_{\mathrm{f}}, 0.50$ (nhexane-acetone; 4:1). It did not give greenish brown color with ferric chloride solution.

Anal. Found: C, 73.78\%; H, 4.76\%; Calc. for $\mathrm{C}_{23} \mathrm{H}_{18} \mathrm{O}_{5} ; \mathrm{C}, 73.80 \%$; $\mathrm{H}, 4.81 \%$. UV $\lambda_{\max }^{\mathrm{MeOH}}: 230,282$ and $375 \mathrm{~nm}$. IR (KBr): 2922, 1647, 1597, 1569, 1544, 1473, 1446, 1430, 1381, 1346, 1326, 1296, 1266, 1245, 1126, 1151, 1110, 1025, 941, 918, 879, 862, $849,833,811,778,760,747,681 \mathrm{~cm}^{-1} .{ }^{1} \mathrm{H}$ NMR $\left(\mathrm{CDCl}_{3}\right): \delta 3.18\left(\mathrm{dd}, 2 \mathrm{H}, \mathrm{C}_{3}-\mathrm{H}\right), 5.06(\mathrm{~s}$, $\left.2 \mathrm{H},-\mathrm{O}-\mathrm{CH}_{2}-\mathrm{C}_{6} \mathrm{H}_{5}\right), 5.32\left(\mathrm{dd}, 1 \mathrm{H}, \mathrm{C}_{2}-\mathrm{H}\right), 6.04\left(\mathrm{~s}, 2 \mathrm{H},-\mathrm{O}-\mathrm{CH}_{2}-\mathrm{O}-\right), 6.35(\mathrm{~d}, 1 \mathrm{H}, J=8.6 \mathrm{~Hz}$, $\left.\mathrm{C}_{6}-\mathrm{H}\right), 6.45\left(\mathrm{~s}, 1 \mathrm{H}, \mathrm{C}_{8}-\mathrm{H}\right), 6.56\left(\mathrm{~m}, 1 \mathrm{H}, \mathrm{C}_{5}{ }^{\prime}-\mathrm{H}\right.$ and $\left.\mathrm{C}_{2}{ }^{\prime}-\mathrm{H}\right), 6.65,\left(\mathrm{~d}, 1 \mathrm{H}, J=9 \mathrm{~Hz}, \mathrm{C}_{6}{ }^{\prime}-\mathrm{H}\right)$, 7.24-7.27 (m, 5H, -O- $\left.\mathrm{CH}_{2}-\mathrm{C}_{6} \mathrm{H}_{5}\right) .7 .60\left(\mathrm{~d}, 1 \mathrm{H}, J=8.6 \mathrm{~Hz}, \mathrm{C}_{5}-\mathrm{H}\right)$.

\subsection{Antibacterial screening}

The antibacterial activities of the compound 4-7 were studied against four human pathogenic bacteria, viz., Shigella dysenteriae $\left(\mathrm{G}^{-}\right)$, Pseudomonas aeruginosa $\left(\mathrm{G}^{-}\right)$, Sarcina lutea $\left(\mathrm{G}^{+}\right)$and Bacillus subtilis $\left(\mathrm{G}^{+}\right)$. For the detection of antibacterial activities, the filter paper disc diffusion method $[24,25]$ was performed.

\subsection{Antifungal screening}

The antifungal activities of compounds 4-7 were studied towards five plant pathogenic and molds fungi, viz., Penicillium sp. (blue molds), Aspergillus nigar (molds), Aspergillus flavus (molds), Candida albicans (human pathogen) and Collectorichum gloesporioides Penz. (plant pathogen). The antifungal activity was assessed by poisoned food technique [26] in some modified condition [27]. Fluconazole (200 $\mu \mathrm{g} / \mathrm{disc})$ was used as standard fungicide for the antifungal activity. Dimethyl sulphoxide (DMSO) was used as a solvent to prepare desired solution $(10 \mathrm{mg} / \mathrm{mL})$ of the compounds initially. Proper control was maintained with dimethyl sulphoxide (DMSO). 


\section{Results and Discussion}

The syntheses of 7-hydroxy-3',4'-methylenedioxyflavanone 6 and 7-benzyloxy-3',4'methyl-enedioxyflavanone $\mathbf{7}$ were accomplished starting from 2,4dihydroxyacetophenone $\mathbf{1}$ as shown in Scheme 1.<smiles>CC(=O)c1ccc(O)cc1O</smiles>

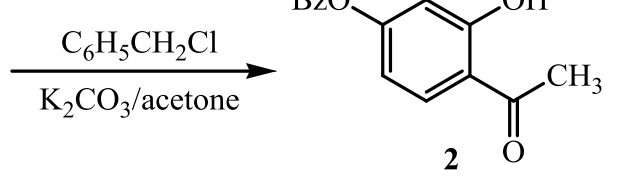<smiles>[R20]O[C@H](O)C[C@H](O)OCCOc1ccc(C=O)cc1OC</smiles>

1. $\mathrm{R}=-\mathrm{H}$

2. $\mathrm{R}=-\mathrm{CH}_{2} \mathrm{C}_{6} \mathrm{H}_{5}$

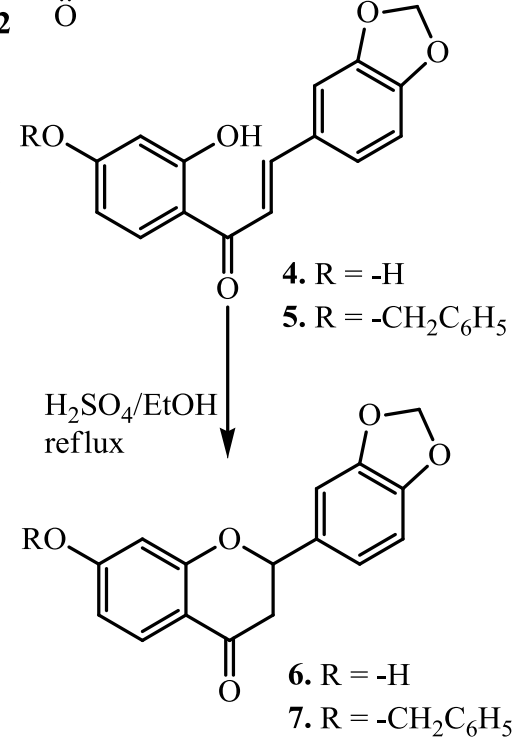

Scheme 1. Synthesis of chalcone and flavanone derivatives.

Aldol condensation of 2,4-dihydroxyaetophyenone 1 with 3,4-methylenedioxy benzaldehyde 3 yielded 2',4'-dihydroxy-3,4-methylenedioxy chalcone 4 . The structure of this chalcone 4 was confirmed by spectral data and elemental analysis. The UV absorption band of compound 4 appeared in $\mathrm{CH}_{3} \mathrm{OH}$ at $\lambda_{\max } 230,265$ and $355 \mathrm{~nm}$, suggesting the presence of a chalcone skeleton [28]. The IR absorption frequency at $v 3410 \mathrm{~cm}^{-1}$ indicated the presence of free hydroxyl group which was supported by positive alcoholic ferric chloride reaction. Other absorption frequency at $v 1675 \mathrm{~cm}^{-1}$ showed the presence of a conjugated carbonyl group $(>\mathrm{C}=\mathrm{O})$. The ${ }^{1} \mathrm{H}$ NMR spectrum explained the methylenedioxy group at $\delta 6.1\left(\mathrm{~s}, 2 \mathrm{H},-\mathrm{O}-\mathrm{CH}_{2}-\mathrm{O}\right)$ as a singlet integrating for two protons. The aromatic protons of A-ring appeared by $\mathrm{ABC}$ system at $\delta 6.32\left(\mathrm{~s}, 1 \mathrm{H}, \mathrm{C}_{3}{ }^{\prime}-\mathrm{H}\right)$. Two hydroxyl protons of A-ring appeared as two singlets at $\delta 11.43\left(\mathrm{C}_{4}{ }^{\prime}-\mathrm{OH}\right)$ and $11.58\left(\mathrm{C}_{2}{ }^{\prime}-\right.$ $\mathrm{OH})$ integrating for one proton each. Two doublets were appeared at $\delta 6.65\left(\mathrm{C}_{5}-\mathrm{H}\right), 6.82$ $\left(\mathrm{C}_{6}-\mathrm{H}\right)$ and one singlet was appeared at $\delta 6.83\left(\mathrm{C}_{2}-\mathrm{H}\right)$ integrating for one proton each. 
Two doublets at $\delta 7.20$ and 7.61 showed the presence of $\mathrm{C}_{\alpha}-\mathrm{H}$ and $\mathrm{C}_{\beta}-\mathrm{H}$ protons, respectively integrating for one proton each.

Oxidation of $2^{\prime}, 4^{\prime}$-dihydroxy-3,4-methylenedioxychalcone 4 into the corresponding flavanone 6 using $\mathrm{H}_{2} \mathrm{SO}_{4} / \mathrm{EtOH}$ reagent was carried out. Compound 6 was obtained as white flakes and has been confirmed by spectral data and elemental analysis. The UV absorption band of compound 6 in methanol at $\lambda_{\max } 232,281$ and $370 \mathrm{~nm}$ indicating the presence of flavanone skeleton. The IR absorption band of flavanone 6 at $\delta 1647 \mathrm{~cm}^{-1}$ showed the presence of carbonyl group $(>C=O)$. Similar IR band (in the range of 16401652) for chelated carbonyl group was observed for other flavanone compounds [29, 30]. The ${ }^{1} \mathrm{H}$ NMR spectrum of flavanone $\mathbf{6}$ indicated the presence of a methylenedioxy group at $\delta 6.01$ as a singlet integrating for two protons. The aromatic protons of both $\mathrm{A}$ and $\mathrm{B}$ rings appeared in a similar manner as was found in its corresponding chalcone 4 . The flavanone 6 also gave a characteristic two double doublets at $\delta 5.44\left(\mathrm{C}_{2}-\mathrm{H}\right)$ and 3.08 $\left(\mathrm{C}_{3}-\mathrm{H}\right)$ integrating for one and two protons, respectively.

Aldol condensation of 2-hyroxy-4-benzyloxy acetophenone 2 with 3,4methylenedioxybenzaldehyde $\mathbf{3}$ yielded 2'-hydroxy-4'-benzyloxy-3,4-methylenedioxy chalcone $\mathbf{5}$. The structure of chalcone $\mathbf{5}$ was confirmed by spectral data and elemental analysis. The UV absorption band of compound 5 appeared in $\mathrm{CH}_{3} \mathrm{OH}$ and at $\lambda_{\max } 232$, 265 and $360 \mathrm{~nm}$ suggested the presence of a chalcone skeleton. The IR absorption frequency at $v 3405 \mathrm{~cm}^{-1}$ indicated the presence of a hydroxyl group which was supported by positive alcoholic ferric chloride reaction. Other absorption frequency at $v 1680 \mathrm{~cm}^{-1}$ showed the presence of a conjugated carbonyl group $(>\mathrm{C}=\mathrm{O})$. The ${ }^{1} \mathrm{H}$ NMR spectrum explained the methylenedioxy group at $\delta 6.02\left(\mathrm{~s}, 2 \mathrm{H},-\mathrm{O}-\mathrm{CH}_{2}-\mathrm{O}\right)$ as a singlet integrating for two protons. The aromatic protons of A-ring appeared by $\mathrm{ABC}$ system at $\delta 6.55$ (s, $\left.1 \mathrm{H}, \mathrm{C}_{3}{ }^{\prime}-\mathrm{H}\right)$. Hydroxyl protons of A-ring appeared as singlet at $\delta 11.58\left(\mathrm{C}_{2}{ }^{\prime}-\mathrm{OH}\right)$ integrating for one proton. Two doublets were appeared at $\delta 6.50\left(\mathrm{C}_{5}-\mathrm{H}\right), 6.65\left(\mathrm{C}_{6}-\mathrm{H}\right)$ and one singlet at $\delta 6.62\left(\mathrm{C}_{2}-\mathrm{H}\right)$ integrating for one proton each. The aromatic protons of $\mathrm{B}$ ring appeared as multiplets at $\delta 7.21-7.26\left(\mathrm{~m}, 5 \mathrm{H},-\mathrm{O}-\mathrm{CH}_{2}-\mathrm{C}_{6} \mathrm{H}_{5}\right)$. Two doublets at $\delta 6.82$ and 7.61 showed the presence of $\mathrm{C}_{\alpha}-\mathrm{H}$ and $\mathrm{C}_{\beta}-\mathrm{H}$ protons, respectively integrating for one proton each.

Oxidation of 2'-hydroxy-4'-benzyloxy-3,4-methylenedioxychalcone 5 into the corresponding flavanone 7 using $\mathrm{H}_{2} \mathrm{SO}_{4} / \mathrm{EtOH}$ reagent was carried out. Flavanone 7 was obtained as white flakes and has been confirmed by spectral data and elemental analysis. The UV absorption band of compound 7 in methanol at $\lambda_{\max } 230,282$ and $375 \mathrm{~nm}$ suggesting the presence of flavanone skeleton. The IR absorption band of flavanone 7 at $\delta 1647 \mathrm{~cm}^{-1}$ showed the presence of carbonyl group $(>\mathrm{C}=\mathrm{O})$ and the absence of a hydroxyl band confirmed the oxidation of chalcone 5 into flavanone 7 . The ${ }^{1} \mathrm{H}$ NMR spectrum of flavanone 7 indicated the presence of a methylenedioxy group at $\delta 6.04$ as a singlet integrating for two protons. The aromatic protons of both A and B ring appeared in a similar manner as were obtained in its corresponding chalcone 5. The flavanone 7 also gave a characteristic two doublets at $\delta 5.32\left(\mathrm{C}_{2}-\mathrm{H}\right)$ and $3.18\left(\mathrm{C}_{3}-\mathrm{H}\right)$ integrating for one and two protons, respectively. 


\subsection{Antibacterial activities}

The antibacterial activities of compounds 4-7 have been assayed at the concentration of $100 \mu \mathrm{g} / \mathrm{disc}, 200 \mu \mathrm{g} / \mathrm{disc}$ and $300 \mu \mathrm{g} / \mathrm{disc}$ against four human pathogenic bacteria. Among them, two were Gram-negative and two were Gram-positive. The inhibitory effects of compounds 4-7 against these organisms are given in Table 1.

Table 1. Results of antibacterial activity of the compounds 4-7 against some selected bacteria.

\begin{tabular}{|c|c|c|c|c|c|}
\hline \multirow[b]{2}{*}{ Bacteria } & \multirow{2}{*}{$\begin{array}{l}\text { Molecular formula } \\
\text { and compound No. }\end{array}$} & \multicolumn{4}{|c|}{ Diameter of the zone of inhibition (mm) } \\
\hline & & $\begin{array}{l}100 \\
\mu \mathrm{g} \operatorname{disc}^{-1}\end{array}$ & $\begin{array}{l}200 \\
\mu \mathrm{g} \operatorname{disc}^{-1}\end{array}$ & $\begin{array}{l}300 \\
\mu \mathrm{g} \mathrm{disc}\end{array}$ & $\begin{array}{l}* \mathrm{~K}-30 \\
\mu \mathrm{g} \operatorname{disc}^{-1}\end{array}$ \\
\hline \multirow{4}{*}{$\begin{array}{l}\text { Shigella } \\
\text { dysenteriae }\left(G^{-}\right)\end{array}$} & $\mathrm{C}_{16} \mathrm{H}_{12} \mathrm{O}_{5}(4)$ & - & - & 7 & \multirow{4}{*}{26} \\
\hline & $\mathrm{C}_{16} \mathrm{H}_{12} \mathrm{O}_{5}(6)$ & - & - & 9 & \\
\hline & $\mathrm{C}_{23} \mathrm{H}_{18} \mathrm{O}_{5}(5)$ & 8 & 11 & 15 & \\
\hline & $\mathrm{C}_{23} \mathrm{H}_{18} \mathrm{O}_{5}(7)$ & 9 & 12 & 14 & \\
\hline \multirow{4}{*}{$\begin{array}{l}\text { Pseudomonas } \\
\text { aeruginosa }\left(G^{-}\right)\end{array}$} & $\mathrm{C}_{16} \mathrm{H}_{12} \mathrm{O}_{5}(4)$ & - & - & - & \multirow{4}{*}{28} \\
\hline & $\mathrm{C}_{16} \mathrm{H}_{12} \mathrm{O}_{5}(6)$ & - & - & 10 & \\
\hline & $\mathrm{C}_{23} \mathrm{H}_{18} \mathrm{O}_{5}(5)$ & - & - & - & \\
\hline & $\mathrm{C}_{23} \mathrm{H}_{18} \mathrm{O}_{5}(7)$ & 11 & 13 & 16 & \\
\hline \multirow{4}{*}{$\begin{array}{l}\text { Sarcina } \\
\text { lutea }\left(G^{+}\right)\end{array}$} & $\mathrm{C}_{16} \mathrm{H}_{12} \mathrm{O}_{5}(4)$ & - & - & - & \multirow{4}{*}{34} \\
\hline & $\mathrm{C}_{16} \mathrm{H}_{12} \mathrm{O}_{5}(6)$ & - & - & 6 & \\
\hline & $\mathrm{C}_{23} \mathrm{H}_{18} \mathrm{O}_{5}(5)$ & - & - & - & \\
\hline & $\mathrm{C}_{23} \mathrm{H}_{18} \mathrm{O}_{5}(7)$ & 10 & 12 & 17 & \\
\hline \multirow{4}{*}{$\begin{array}{l}\text { Bacillus } \\
\text { subtillis }\left(G^{+}\right)\end{array}$} & $\mathrm{C}_{16} \mathrm{H}_{12} \mathrm{O}_{5}(4)$ & - & - & - & \multirow{4}{*}{30} \\
\hline & $\mathrm{C}_{16} \mathrm{H}_{12} \mathrm{O}_{5}(6)$ & - & - & 10 & \\
\hline & $\mathrm{C}_{23} \mathrm{H}_{18} \mathrm{O}_{5}(5)$ & - & - & - & \\
\hline & $\mathrm{C}_{23} \mathrm{H}_{18} \mathrm{O}_{5}(7)$ & - & - & 12 & \\
\hline
\end{tabular}

The screening results indicate that compound $\mathbf{4}$ didn't show any antibacterial activity to the tested bacteria except against Shigella dysenteriae $\left(G^{-}\right)$at high concentration and compound 5 showed marked antibacterial activity only against Shigella dysenteriae $\left(G^{-}\right)$, compound $\mathbf{6}$ showed antibacterial activity to the all tested bacteria at high concentration. Compound 7 showed moderate antibacterial activities against Shigella dsenteriae $\left(G^{-}\right)$, Pseudomonas aeruginosa $\left(G^{-}\right)$and Sarcina lutea $\left(G^{+}\right)$.

\subsection{Antifungal activities}

The antifungal activities of compounds 4-7 have been assayed at the concentration of 100 $\mu \mathrm{g} / \mathrm{disc}, 200 \mu \mathrm{g} / \mathrm{disc}$ and $300 \mu \mathrm{g} / \mathrm{disc}$ against five plant pathogenic and molds fungi. The inhibitory effects of compounds 4-7 against these organisms are given in Table 2. 
Table 2. Results of antifungal activity of the compounds 4-7 against some selected antifungals.

\begin{tabular}{|c|c|c|c|c|c|}
\hline \multirow[b]{2}{*}{ Fungi } & \multirow{2}{*}{$\begin{array}{l}\text { Molecular formula } \\
\text { and compound No. }\end{array}$} & \multicolumn{4}{|c|}{ Diameter of the zone of inhibition (mm) } \\
\hline & & $\begin{array}{l}100 \\
\mu \mathrm{g} \operatorname{disc}^{-1}\end{array}$ & $\begin{array}{l}200 \\
\mu \mathrm{g} \operatorname{disc}^{-1}\end{array}$ & $\begin{array}{l}300 \\
\mu \mathrm{g} \operatorname{disc}^{-1}\end{array}$ & $\begin{array}{l}\text { Fluconazole } \\
200 \mu \mathrm{g} / \text { disc }\end{array}$ \\
\hline \multirow{4}{*}{ Penicillium sp. } & $\mathrm{C}_{16} \mathrm{H}_{12} \mathrm{O}_{5}(4)$ & - & - & - & \multirow{4}{*}{25} \\
\hline & $\mathrm{C}_{16} \mathrm{H}_{12} \mathrm{O}_{5}(6)$ & - & - & - & \\
\hline & $\mathrm{C}_{23} \mathrm{H}_{18} \mathrm{O}_{5}(5)$ & - & 6 & 10 & \\
\hline & $\mathrm{C}_{23} \mathrm{H}_{18} \mathrm{O}_{5}(7)$ & 9 & 14 & 16 & \\
\hline \multirow{4}{*}{$\begin{array}{l}\text { Aspergillus } \\
\text { nigar }\end{array}$} & $\mathrm{C}_{16} \mathrm{H}_{12} \mathrm{O}_{5}(4)$ & - & - & - & \multirow{4}{*}{25} \\
\hline & $\mathrm{C}_{16} \mathrm{H}_{12} \mathrm{O}_{5}(6)$ & - & - & - & \\
\hline & $\mathrm{C}_{23} \mathrm{H}_{18} \mathrm{O}_{5}(5)$ & - & 4 & 6 & \\
\hline & $\mathrm{C}_{23} \mathrm{H}_{18} \mathrm{O}_{5}(7)$ & - & 7 & 9 & \\
\hline \multirow{4}{*}{$\begin{array}{l}\text { Aspergillus } \\
\text { flavus }\end{array}$} & $\mathrm{C}_{16} \mathrm{H}_{12} \mathrm{O}_{5}(4)$ & - & - & - & \multirow{4}{*}{25} \\
\hline & $\mathrm{C}_{16} \mathrm{H}_{12} \mathrm{O}_{5}(6)$ & - & - & - & \\
\hline & $\mathrm{C}_{23} \mathrm{H}_{18} \mathrm{O}_{5}(5)$ & - & - & - & \\
\hline & $\mathrm{C}_{23} \mathrm{H}_{18} \mathrm{O}_{5}(7)$ & - & 9 & 11 & \\
\hline \multirow{4}{*}{$\begin{array}{l}\text { Candida } \\
\text { albicans }\end{array}$} & $\mathrm{C}_{16} \mathrm{H}_{12} \mathrm{O}_{5}(4)$ & - & - & - & \multirow{4}{*}{28} \\
\hline & $\mathrm{C}_{16} \mathrm{H}_{12} \mathrm{O}_{5}(6)$ & - & - & - & \\
\hline & $\mathrm{C}_{23} \mathrm{H}_{18} \mathrm{O}_{5}(5)$ & 5 & 8 & - & \\
\hline & $\mathrm{C}_{23} \mathrm{H}_{18} \mathrm{O}_{5}$ & - & 18 & 23 & \\
\hline \multirow{4}{*}{$\begin{array}{l}\text { Colletorichum } \\
\text { gloeosporioides }\end{array}$} & $\mathrm{C}_{16} \mathrm{H}_{12} \mathrm{O}_{5}(4)$ & - & - & - & \multirow{4}{*}{25} \\
\hline & $\mathrm{C}_{16} \mathrm{H}_{12} \mathrm{O}_{5}(6)$ & - & - & - & \\
\hline & $\mathrm{C}_{23} \mathrm{H}_{18} \mathrm{O}_{5}$ (5) & 5 & 6 & - & \\
\hline & $\mathrm{C}_{23} \mathrm{H}_{18} \mathrm{O}_{5}$ & - & 8 & 11 & \\
\hline
\end{tabular}

The screening results indicate that compound $\mathbf{4}$ and $\mathbf{6}$ did not show any antifungal activities to the tested fungi. On the other hand, compound $\mathbf{5}$ showed little antifungal activities against all tested fungi except Aspergillus flavus while compound $\mathbf{7}$ showed good antifungal activities to the all tested fungi in comparison with standard fungicides, fluconazole.

\section{Conclusion}

Two flavanones, 7-Hydroxy-3',4'-methylenedioxy flavanone 6 and 7-benzyloxy-3', 4'methylenedioxy flavanone 7 were synthesized, purified and characterized. Antibacterial and antifungal screening were performed against some human pathogenic bacteria and plant pathogenic \& molds fungi, respectively. The flavanone 6 showed very little antibacterial activity with almost no antifungal activity. On the other hand flavanone 7 showed good antibacterial and antifungal activities against the selected bacterial and fungal strains. 


\section{Acknowledgments}

The author are thankful to Mr. A. F. M. Motiur Rahman, Ph.D. fellow, College of Pharmacy, Yeungnum University, Gyeongsan 712749, South Korea for recording valuable ${ }^{1} \mathrm{H}$ NMR, IR spectra and elemental analysis of the synthesized compounds. We also thankful to Dr. Md. Shahidul Alam, Associate Professor, Department of Botany, University of Rajshahi for providing fungus, bacteria and laboratory facilities.

\section{References}

1. S. Alam, P. Satpathy, and A. Thosar, Int. Res. J. Pharm. 5(4), 244 (2014). https://doi.org/10.7897/2230-8407.050452

2. J. B. Harborne and H. Baxter, The Handbook of Natural Flavonoids (Wiley and Sons, Chichester, United Kingdom, 1991).

3. S. Kuntz, U. Wenzel, and H. Daniel, Eur. J. Nutr. 38(3), 133 (1999). https://doi.org/10.1007/s003940050054

4. C. M. Lu and C. N. Lin, Phytochemistry 33(4), 909 (1993). https://doi.org/10.1016/0031-9422(93)85302-8

5. C. M. Lu and C. N. Lin, Phytochemistry 35(3), 781 (1994). https://doi.org/10.1016/S0031-9422(00)90605-8

6. Y. K. Rao, P. Harikishore, C. V. Rao, A. G. Blond, and B. Bodo, Phytochemistry 61(8), 927 (2002). https://doi.org/10.1016/S0031-9422(02)00389-8

7. N. Masayuki and K. Mamoru, Minor Flavonoids, Chalcones, Flavanones, Dihydrochalcones, and Aurones in Natural products, edited by $K$. G. Ramawat (Springer Verlag, Verlin Heidelberg, 2013) pp. 1867-1900.

8. C. Pouget, F. Lauthier, A. Simon, C. Fagnere, J. P. Basly, C. Delage, and A. Chulia, Bioorg. Med. Chem. Lett. 11(24), 3095 (2001). https://doi.org/10.1016/S0960-894X(01)00617-5

9. K. V. Rao, S. K. Chattopadhyay, and G. C. Reddy, J. Agric. Food Chem. 38(6), 1427 (1990). https://doi.org/10.1021/jf00096a028

10. M. Weidenbormer and H. C. Jha, Pest Management Sci. 38(4), 347 (1993). https://doi.org/10.1002/ps.2780380412

11. A. M. Silva, M. Weidenborner, and J. A. S. Cavaleiro, Mycol. Res. 102(5), 638 (1998). https://doi.org/10.1017/S0953756297005480

12. I. Jacob, Intermolecular and Surface Forces, $2^{\text {nd }}$ Edition (Academic Press, London, 1992).

13. T. Coussaert and M. Baus, Phys. Rev. E52, 862 (1995). https://doi.org/10.1103/PhysRevE.52.862

14. M. Baus, T. Coussaert, and R. Achrayah, Physica A A232(3-4), 575 (1996). https://doi.org/10.1016/0378-4371(96)00167-7

15. W. B. Russei, D. A. Saville, and W. A. Schowalter, Colloidal Dispersions, $2^{\text {nd }}$ Edition (Cambridge University Press, Cambridge, 1991).

16. R. Raturi R, S. C. Sati, P. P. Badoni, H. Singh, and M. D. Sati, J. Sci. Res. 4(3), 769 (2012).

17. S. Alam, Z. Sarkar and A. Islam, J. Chem. Sci. 116(1), 29 (2004). https://doi.org/10.1007/BF02708210

18. S. Alam, M. A. J. Miah, and A. Islam, J. Biological. Sci. 4(4), 527 (2004). https://doi.org/10.3923/jbs.2004.527.531

19. S. Alam, Acta Chim. Slov. 51, 447 (2004).

20. S. Alam and S. Mostahar, J. Appl. Sci. 5(2), 327 (2005). https://doi.org/10.3923/jas.2005.327.333

21. S. Alam, J. Chem. Sci. 116(6), 325 (2004). https://doi.org/10.1007/BF02711433

22. S. Alam, M. A. J. Miah, and A. Islam, ACGC Chem. Res. Comm. 18, 1 (2005). 
23. A. Rahim, R. Ali, and A. Islam, J. Sci. Res. 8(2), 209 (2016). https://doi.org/10.3329/jsr.v8i2.26622

24. H. Arima, H. Ashida, and G. I. Danno, Biosci. Biotechnol. Biochem. 66(5), 1009 (2002). https://doi.org/10.1271/bbb.66.1009

25. K. Jeongmok, R. M. Maurice, and I. W. Cheng, J. Agr. Food Chem. 43, 2834 (1995).

26. R. K. Grover and J. D. Moore, Phytopathology 52, 876 (1962).

27. M. A. T. Miah, H. U. Ahmed, N. R. Sharma, A. Ali, and S. A. Miah, Bangladesh J. Bot. 19(1), 5 (1990).

28. L. Cannonica, B. Rindone, E. Santaniello, and C. Scolastico, Tetrahedron Lett. 2691 (1971). https://doi.org/10.1016/S0040-4039(01)96954-0

29. X. Q. R. Sheela, P. Arockiasamy, R. Kanmani, A. Charles, and V. A. Ramani, J. Chem. Pharm. Res. 3(2), 762 (2011).

30. S. Hammami, H. B. Jannet, A. Bergaoui, L. Ciavatta, G. Cimino, and Z. Mighri, Molecules 9(7), 602 (2004). https://doi.org/10.3390/90700602 